\title{
Emergencies in cardiovascular surgery
}

\author{
Z Mitrev, T Anguseva* \\ From 23rd World Congress of the World Society of Cardio-Thoracic Surgeons \\ Split, Croatia. 12-15 September 2013
}

\section{Background}

Urgent surgery is part of a daily practice on cardiovascular units, and it may be required in patients with conditions such as acute coronary syndrome, endocarditis and valvular diseases, trauma, acute aortic dissection as well as acute vascular embolisations and Leriche syndrome.

\section{Methods}

In emergency situation, preoperative patient work-up for cardio-vascular surgery is quite different from the elective setting. Since 03/2000 till 01/2012 we have analyzed a consecutive series of 12172 cases out of which 2214 underwent emergency procedures (18.19\%). The most frequent problems requiring urgent intervention were thoracic aortic aneurysms (448 cases; 20.24\%); coronary artery disease (1006 cases; $45.47 \%$ ) abdominal aortic aneurysms (125 cases - 66 with rupture; $2.96 \%)$, peripheral vascular (364 cases; $16.46 \%$ ), and others (329 cases: $14.87 \%)$.

\section{Results and discussion}

Urgent thoracic and abdominal aortic aneurysm repair accounted for $23 \%$ respectively and the corresponding proportion for peripheral vascular surgery is $16 \%$. However, urgent surgery for acute coronary ischemia, valvular and congenital heart disease accounted for somewhat less than $60 \%$ for each group of these pathologies. Mortality rate was $43(1.91 \%)$.

\section{Conclusion}

Systematic pre-operative diagnostic work-up is a recognized tool for procedure related risk assessment and superior management of diseases. However, hemodynamic instability and other time related events correlated with negative outcome, are the main driving forces for accelerated diagnostic pathways.

\footnotetext{
* Correspondence: tanja@cardiosurgery.com.mk

Special Hospital for Surgery Fillip II, Skopje, Macedonia
}

Published: 11 September 2013

doi:10.1186/1749-8090-8-S1-O2

Cite this article as: Mitrev and Anguseva: Emergencies in cardiovascular surgery. Journal of Cardiothoracic Surgery 2013 8(Suppl 1):O2.
Submit your next manuscript to BioMed Central and take full advantage of:

- Convenient online submission

- Thorough peer review

- No space constraints or color figure charges

- Immediate publication on acceptance

- Inclusion in PubMed, CAS, Scopus and Google Scholar

- Research which is freely available for redistribution
() Biomed Central

\section{( Biomed Central}

(c) 2013 Mitrev and Anguseva; licensee BioMed Central Ltd. This is an Open Access article distributed under the terms of the Creative Commons Attribution License (http://creativecommons.org/licenses/by/2.0), which permits unrestricted use, distribution, and reproduction in any medium, provided the original work is properly cited. 